Helena Näs has taught biology, chemistry and mathematics for ten years in secondary and upper secondary schools, before becoming a lecturer at the Department of Mathematics Technology and Science Education, Umeå University. After three years as a lecturer at teacher education she started as a doctoral student in biology didactics at the Department of Ecology and Environmental Science, Umeå University.

Christina Ottander, Ph.D. in Plant Physiology and senior lecturer at the Department of Mathematics Technology and Science Education, Umeå University. Her research interest concern both socio-scientific issues and their ability to improve students' interest and learning and teachers' ability to work with scientific inquiry.

HELENA NÄS

Department of Ecology and Environmental Science,

Umeå University, Sweden

Helena.nas@educ.umu.se

\title{
Student reasoning while investigating plant material
}

\begin{abstract}
In this project, 10-12 year old students in three classes, investigated plant material to learn more about plants and photosynthesis. The research study was conducted to reveal the students'scientific reasoning during their work. The eleven different tasks helped students investigate plant anatomy, plant physiology, and the gases involved in photosynthesis and respiration. The study was carried out in three ordinary classrooms. The collected data consisted of audio-taped discussions, students' notebooks, and field notes. Students' discussions and written work, during the different plant tasks, were analysed to see how the students' learning and understanding processes developed. The analysis is descriptive and uses categories from a modified general typology of student's epistemological reasoning. The study shows students' level of interest in doing the tasks, their struggle with new words and concepts, and how they develop their knowledge about plant physiology. The study confirms that students, in this age group, develop understanding and show an interest in complicated processes in natural science, e.g. photosynthesis.
\end{abstract}

\section{INTRODUCTION}

Students at almost all school levels, from 9 to 19 years of age, show similar misconceptions about photosynthesis and respiration (Andersson, 2000; Bornäs \& Djurvall, 1993; Canal, 1999; Carlsson, 1999; 2002; 2003; Ekborg, 2003; Harlen, 2001; Marmaroti \& Galanopoulou, 2006; Smith \& Anderson, 1984; Wood-Robinson, 1991; Özay, 2003). There seems to be a fundamental lack of understanding of basic ecological concepts, e.g. the importance of plants on earth and energy flow in ecosystems, including the role of photosynthesis for life on earth. When photosynthesis is not truly understood the students tend to use rote learning as a learning strategy and the knowledge about photosynthesis doesn't get meaningful for them (Canal, 1999). According to the review by Canal (1999), primary school students had little practical experience of plant structures and functional processes. He suggested that further research is needed about how changes can be implemented in the primary school curriculum to give students opportunities to learn photosynthesis in a useful way. Another study looking at students' understanding of photosynthesis, noted that when teaching is too matter-based, i.e. words and concepts without context, the process of, for example, photosynthesis is not learned properly (Barak, 1999). 
Several studies report that students from 6-12 years old are curious and not frightened to communicate science in school and they have the potential to investigate science (Gallas, 1995; Harlen, 2001; Nilsson, 2005; Tytler \& Peterson, 2003; Vikström, 2005). According to these studies, young children are capable of more than current curricula recommend and demand in the school system. Therefore, it was of interest to conduct further studies into the learning of science in primary schools, specifically on students doing investigations.

Many studies show that teachers need to challenge their students if they want them to use reasoning regarding empirical data (Andersson, Bach, Hagman et al., 2005; Helldén, 1992; 2002; 2005; Lidar, Lundqvist \& Östman, 2006; Sjøberg, 2000; Vikström, 2005; Zetterqvist, 2003). Students need to be confronted with challenging questions while doing their tasks or else they tend to think about and interpret the results as they have done previously. Thus, teachers play an important role during lessons (ibid.). The plan of action for science education by The Swedish National Agency for School Improvement (2005) concluded that science classes should make more use of discussions, investigations, and laboratory work to raise the level of interest in science (cf. Andersson, Bach, Hagman et al., 2005). They also pointed out the importance of listening to students' language before and during the introduction of science content in the classroom.

Dysthe (2003) writes about socio-cultural perspectives of knowledge and learning, using cognitive theories, together with socio-cultural views. She refers to learning theorists like Dewey, Mead and Vygotsky when she writes about the importance of the social group for individual learning. Dysthe sheds light on the complex interplay between individual and group, cognition and culture, thought and language, communication and contents and she means that these dichotomies are impossible to separate from each other. Aspects of both individual and socio-cultural views are needed to view the understanding and learning processes in the classroom (Leach \& Scott, 2003; Rivard \& Straw, 2000). Barnes and Todd (1995) suggest that learning is a reconstruction of earlier knowledge with reinterpretations and a reshaping of new and old knowledge. In an ongoing dialogue with other students, new or deepened knowledge about scientific phenomena can help individual students to formulate questions and to learn. Students, who manage to do this in her/his actions, have reached understanding (ibid.).

Knowledge about students' reasoning gives the teacher interesting insights and opportunities to support and help students (Barnes \& Todd, 1978; 1995; Driver, Leach, Millar \& Scott, 1996; Tytler \& Peterson, 2003). In Barnes and Todd's (1978) analysis of children's discussions about specific tasks, they categorised social and cognitive functions of learning conversations between students to understand whether students' talk and interplay leads to new knowledge or not. Their categorisation of students' reasoning describes a deepened understanding and learning process (ibid). Driver et al. (1996) and Tytler and Peterson (2003) illuminated students' understanding in group and individual interviews by using three epistemological representations of students' reasoning. Since scientific reasoning depends on the context, it is of interest to analyse students' discussions and writings in their ordinary classrooms.

This study will complement the above mentioned studies on student knowledge and misconceptions about photosynthesis and respiration, by describing how students develop their scientific reasoning and understanding about plants, plant life cycles and photosynthesis while working with plant material in a classroom context. The following research questions were explored:

- How do students develop scientific reasoning during their investigation of plant material?

- What do students' discussions and written work reveal about their level of interest to comprehend and their learning and understanding in the beginning, during and after investigation of plant material? 


\section{METHOD}

\section{The school, students, and the teachers}

Sixty-eight school children aged from 10 to 12 years, from a town in northern Sweden participated in this study. Three classes (4-6 graders) and four of their teachers were involved. The school has about 300 students (1-6 graders) every year. Many of the children's parents work in an industry located near the school. Most families live in their own houses and the school is located in the middle of the residential area.

The choice of classes depended on whether the teachers were interested in participating. All teachers involved had more than ten years of teaching experience, but none of them had qualifications in biology. The teachers were interested and willing to learn new biology content for their teaching. In a letter sent to students' home addresses, parents were informed about the project. All students were interested in participating and their parents approved our presence and the project design. The project follows the Swedish ethical principals in research (Vetenskapsrådet, 2002).

\section{Design}

We designed plant tasks and teaching sequences that encouraged students to observe, reflect on, and discuss plant material. The tasks were constructed to give the students empirical references to plant structures and functional processes (cf. Canal 1999) and the questions that followed each task challenged the students to discuss new words and concepts about plants and photosynthesis (cf. Andersson, Bach, Frändberg et al., 2005); Barak, 1999; Helldén, 1992; 2002; 2005; Lidar et al., 2006; Sjøberg, 2000; Vikström, 2005). Also, a few theory lessons were given. This design followed the plan of action for science education by the Swedish National Agency for School Improvement (2005) and it also made it possible for us to focus on the students reasoning during their work.

The study was carried out over a six-week period with teaching sessions as described in Table 1 . The subject content and the tasks were new to the students. None of the three classes had used microscopes or magnifiers in the classroom before.

The teaching sessions included eleven different tasks which demonstrated plant anatomy, cells, the gases oxygen and carbon dioxide by different reagents, and introduced new concepts/words. The students worked in groups of two or three students. In the first week (Table 1), the groups circulated and worked with five different plant tasks and on the next occasion (in the fourth week) with the remaining six tasks. An instruction given at each task (exemplified below) asked the students to use all their senses during the observations and investigations. The students were encouraged to document their questions and thoughts. There were also two or three questions in each instruction (exemplified below) aimed at helping the students focus on the task. Students' discussions at the different tasks were audio-taped in all classes. In most of these discussions, there were no interactions with teachers, but the teachers were available if the students asked for help.

Our aim with the tasks was to give students an opportunity to study plants and their life cycle. We sorted the tasks into three groups from visible, almost visible and to invisible matter (1-3). The different tasks within each group were: 1 . Seeds and germs; visible to the eye, touchable and possible to taste and smell. 2. Plant cells and stomata; only visible when using a microscope and magnifier and planned as a link between the plant and the invisible process of photosynthesis. 3. Gases; invisible but possible to indicate. All tasks were constructed in a similar way, here exemplified by the seed task as follows: The students were told to look at the different seeds thoroughly and to use magnifiers and split dry and wet seeds. They were also instructed to write down observations in their notebooks. The next step was to discuss and answer two or three questions, in their own words. The questions in this specific task were: Do seeds live? Do seeds breathe? 
The students only used their own and the teachers knowledge when they investigated the plant material and tried to answer the questions. The students had no books or internet available.

Table 1. Overview of teaching sessions during the project. The article focuses on the first, fourth and sixth week, including the interviews six months later.

\begin{tabular}{|c|c|c|c|}
\hline Week & $\begin{array}{l}\text { Activities carried out in each of the three } \\
\text { classes }\end{array}$ & Data acquisition & $\begin{array}{l}\text { Analysis } \\
\text { method }\end{array}$ \\
\hline 1 & $\begin{array}{l}\text { Five different plant tasks about plant anatomy } \\
\text { and plant life cycles. Audio-taped group } \\
\text { discussions. Students recorded details in their } \\
\text { notebooks. }\end{array}$ & $\begin{array}{l}\text { Discussions and } \\
\text { written work tran- } \\
\text { scribed. } 17 p p\end{array}$ & $\begin{array}{l}\text { Categorising } \\
\text { reasoning }\end{array}$ \\
\hline 2 & $\begin{array}{l}\text { Home investigations with garden cress culti- } \\
\text { vated in darkness and light. }\end{array}$ & $\begin{array}{l}\text { Notebooks re- } \\
\text { viewed }\end{array}$ & \\
\hline 3 & $\begin{array}{l}\text { Theory lessons including concepts concerning } \\
\text { the plant tasks and a carbon story. Students } \\
\text { recorded details in their notebooks. }\end{array}$ & $\begin{array}{l}\text { Notebooks re- } \\
\text { viewed }\end{array}$ & \\
\hline 4 & $\begin{array}{l}\text { Four tasks to investigate carbon dioxide and } \\
\text { water. Demonstrations of tasks with oxygen } \\
\text { and sugar. Audio-taped discussions. Stu- } \\
\text { dents recorded details in their notebooks. }\end{array}$ & $\begin{array}{l}\text { Discussions and } \\
\text { written work tran- } \\
\text { scribed. } 17 p p\end{array}$ & $\begin{array}{l}\text { Categorising } \\
\text { reasoning }\end{array}$ \\
\hline 5 & $\begin{array}{l}\text { Questionnaire with } 10 \text { multiple-choice ques- } \\
\text { tions (Andersson, Bach, Frändberg et al., } \\
\text { 2005). } n=66 \text {. }\end{array}$ & $\begin{array}{l}\text { Frequency and } \\
\text { cross tabulation }\end{array}$ & $\begin{array}{l}\text { Statistical } \\
\text { pro-gramme } \\
\text { (SPSS9.0) }\end{array}$ \\
\hline 6 & $\begin{array}{l}\text { Two group interviews with two boys and two } \\
\text { girls from each class. }\end{array}$ & $\begin{array}{l}5^{\text {th }} \text { grade tran- } \\
\text { scribed } 4^{\text {th }} \text { grade } \\
\text { partly transcribed. } \\
6 p p\end{array}$ & $\begin{array}{l}\text { Categorising } \\
\text { reasoning }\end{array}$ \\
\hline 30 & $\begin{array}{l}\text { Individual interviews with three girls and } \\
\text { two boys in fifth grade, lasting about 30-35 } \\
\text { minutes. }\end{array}$ & $\begin{array}{l}\text { All transcribed. } \\
\text { 33pp }\end{array}$ & $\begin{array}{l}\text { Categorising } \\
\text { reasoning }\end{array}$ \\
\hline
\end{tabular}

In the first and fourth week, when the tasks were carried out, the first author started the lessons and acted as a co-teacher together with the ordinary teachers, while the students were working in groups with their tasks.

\section{Data collection and analysis}

The article focuses on the first, fourth and sixth week, including the interviews six months later. During first and fourth week, the first author visited each classroom, for about 90 minutes, as an experienced biology teacher and as an observing researcher. Field notes were kept during the lessons, although most notes were written after the lesson in a separate room. In the sixth week (Table 1) and six months later the students were interviewed. The fourth and fifth graders' teachers were told to pick two boys and two girls to each group interview in the sixth week. To the individual interviews the fifth graders teacher was told to pick five average achieving students who hadn't been involved in the group interview. In both individual and group interviews the students were confronted with pine tree branches, potatoes, carrots and two pot plants, together with questions connected to the project. Questions about photosynthesis were formulated both implicitly and explicitly. 
Data collected in the study include audio-taped student discussions, observations during the lessons and collection of students' notations. Students' discussions, written records and the interviews were transcribed and analysed. The transcripts comprise 73 pages. Using Driver's et al. (1996) and Tytler and Peterson's (2003) epistemological representations of student reasoning and Barnes and Todd's (1978) interaction and cognition in analysing speech events, we found a way to describe and organise students' reasoning from both discussions, written records and interviews .

Barnes and Todd's (1978) categorisation of students' reasoning describes a deepened understanding and learning process. Their categories are:

- Discourse moves; characterised by discussions between the students about the task, rather than other matters.

- Logical process; characterised by students trying to solve a problem.

- Social domain; characterised by the progress, conflicts, supportive behaviour, etc. in the group.

- Cognitive strategies; characterised by students' discussions leading to understanding

- Reflexive thoughts; characterised by students' amalgamation of new and previous knowledge

These categories describe two levels in both cognitive and social functions. At the first level, discourse moves and logical processes are represented and the second level is represented by social domain, cognitive strategies, and reflexive thoughts (Barnes \& Todd, 1978). Since this study focuses on the cognitive functions, categories in social functions will not be further mentioned.

When Barnes and Todd (1978) analysed students' discussions, they divided the cognitive functions into two levels i.e. logical processes and cognitive strategies, plus reflexivity. They meant that students' discussions could be logical in the procedure when they constructed patterns to explain what happened and that this could lead to a new constructing way of understanding, i.e. cognitive strategies and reflexive thoughts. Barnes and Todd's categories are convenient for this study since they have been used to analyse students' discussions, without intervening teachers. Similarly, Driver et al. (1996) and Tytler and Peterson (2003) employ three epistemological representations of students reasoning, where they illuminate students' understanding. They wanted to explore the relationship between reasoning and knowledge and the students' approach to exploration (ibid.). They used three categories:

- Phenomenon-based: Use all senses to observe and find out new things. Using non-scientific language and metaphors. No explanations.

- Relation based: Describe new things and compare with what they already know. Discuss and explain from questions and instructions in the task and learn from peers and teachers.

- Concept or model based: Make connections with new scientific words and previous scientific knowledge. The reasoning shows understanding of concepts or scientific processes that can be explained by using scientific models.

The epistemological representations referred to above were used to analyse both pair interviews and empirical inquiry, of students that were 9, 12, and 16 years old (ibid). Tytler and Peterson (2003) build on the work of Driver's et al (1996) representations when they analysed interviews of younger students ( 5 and 6 years old) during their two first years in primary school. This way of describing and analysing students' reasoning also coincide well with the context of the present study. In contrast to Barnes and Todd (1978), Driver et al. (1996) only have a theoretical hierarchy and represent no development sequences. They also suggest that anyone of the three forms of reasoning could appear in specific science situations and: 
In our analysis, we used a combination of Driver's et al. (1996) epistemological representations of students' reasoning and Barnes and Todd's $(1978 ; 1995)$ analysis of children talking about specific tasks (Table 2). With this combination we formulated an analysis method which suited both students' group discussions, written reports and the interviews. In the analysis, we tried to establish what the students' reasoning could tell us about their learning process and how they developed understanding.

Table 2. Reasoning perspectives for analysing levels of understanding in students' discussions (modified after Barnes and Todd's (1978) speech events and Driver's et al. (1996) and Tytler and Peterson's (2003) epistemological reasoning framework).

\begin{tabular}{|c|c|c|}
\hline $\begin{array}{l}\text { Phenomenon based reason- } \\
\text { ing }\end{array}$ & $\begin{array}{l}\text { Logical processes and rela- } \\
\text { tion based reasoning }\end{array}$ & $\begin{array}{l}\text { Cognitive strategies, } \\
\text { reflexive thoughts and } \\
\text { concept / model based } \\
\text { reasoning }\end{array}$ \\
\hline $\begin{array}{l}\text { Observing the world. } \\
\text { No explanations. } \\
\text { Students only talk about their } \\
\text { observations. } \\
\text { A focus on the subject content. } \\
\text { To see, feel, smell and find out } \\
\text { new things. } \\
\text { e.g. excerpt } 1 \text { and } 7\end{array}$ & $\begin{array}{l}\text { Describe and explain new } \\
\text { things. } \\
\text { Compare with what they al- } \\
\text { ready know. } \\
\text { Explanations out of data. } \\
\text { No general scientific theories. } \\
\text { Discuss and ask questions } \\
\text { from instructing questions. } \\
\text { Learn from peers and teachers. } \\
\text { e.g. excerpt } 2 \text { and } 3\end{array}$ & $\begin{array}{l}\text { Make connections with new } \\
\text { words/concepts in a way } \\
\text { that shows understanding } \\
\text { for scientific processes and } \\
\text { theories. } \\
\text { e.g. excerpt } 3 \text { and } 6\end{array}$ \\
\hline
\end{tabular}

When students' discussions consist of the three perspectives (Table 2) mixed together, their reasoning shows understanding. Our analysis is descriptive and will illustrate students' use of scientific and every-day language, how they compare, and how they try to use new scientific words and concepts during their work with plant material.

\section{RESULTS}

During the six-week long teaching session with tasks concerning photosynthesis, home investigation, and theory lessons, the students showed an astonishing activity in all tasks. In the fifth grade the classroom situation was noisier than in the fourth grade. The sixth graders were calm and less engaged. All students observed plants, seeds, germs and plant cells, and investigated the gases involved in photosynthesis. The excerpts come from students' audio-taped talk and their written records, and the excerpts presented below gives a fair description of the discussions in all three classes. The audio-taped excerpts focus on students' group discussions and no individual students are followed in the group. The excerpts are marked with $\mathrm{S}_{1}-\mathrm{S}_{3}$ to show that all students participated in the discussions. There are no teachers involved in the shown excerpts. The multiple reasoning perspectives (Table 2) are used in the analysis of all excerpts to present the students' elaboration of understanding. The students' development of scientific reasoning will be presented according to the investigations of the tasks named visible, almost visible and invisible. 


\section{Visible matter - garden cress, seeds and germs}

The students were most familiar with the visible tasks since they encounter seeds, germs and plants in their daily life. Excerpt 1 shows phenomenon based reasoning, how they move within the discourse and examples of the students' comparisons. In this sequence, three students in the fourth grade (10 years old) were looking at wet garden cress seeds and cultivated garden cress using a magnifier.

\section{Excerpt 1}

$\mathrm{S}_{1}: \ldots$ try this

$\mathrm{S}_{2}: \ldots$ no, we want to look at this first

$\mathrm{S}_{1}: \ldots$ but try this, this is really something!

$\mathrm{S}_{3}$ : Wow, look at this...

$\mathrm{S}_{1}$ :... try this, this is really fun!

$\mathrm{S}_{2}$ :... what a bad smell

$\mathrm{S}_{3}$ : I want to look at this instead (looking through a magnifier). It looks like popcorn ...

$\mathrm{S}_{1}$ : Does it?

$\mathrm{S}_{3}$ : Yeeeah, but not like ...

$\mathrm{S}_{2}$ : It smells! Try this one! Have a smell? ... (reacts to the smell of the garden cress)

$\mathrm{S}_{1}$ : Do you want to smell? It's free ... It's food!

$\mathrm{S}_{3}$ : I will taste it!

$\mathrm{S}_{1}$ : Everything that smells doesn't need to taste good.

$\mathrm{S}_{2}$ : I hold my nose and look (takes a deep breath)

$\mathrm{S}_{1}$ : ... I really want to see this one ... could we change?

$\mathrm{S}_{3}$ : Look! ... it's like a jungle! (looking at three days cultivated garden cress with a magnifier)

$\mathrm{S}_{1}$ : Aaaaaah ... this is dirty!

$\mathrm{S}_{3}$ : Look at this, it's like a jungle!

$\mathrm{S}_{2}$ : It looks like roe ... (fish eggs)

$\mathrm{S}_{3}$ : Do you want to see? ... Have you seen this? Have a look at this!

$\mathrm{S}_{1}$ : Ahh, yucky! ... (turns to the other peer) ... Is this the jungle?

Their fascination dominates the sequence and there was little use of scientific language in their informal discussions, but their questions showed that scientific interest was stimulated from their new experiences. The fourth graders above used a phenomenon based reasoning (cf. Table 2). However, their questions and explanations from the whole data collection categorised most of their reasoning as relation based. The enthusiasm and curiosity in fourth and fifth graders work generally lengthened their discussions e.g. the speed of the growing garden cress made them wonder about the biological process of germination. Questions like: when do they germinate, when are they fully germinated and do they need light to germinate, surfaced at many of the visible tasks. The students wanted to know more and they explained and tried to convince one another in their explanations. Excerpt 2 with three students in fifth grade illustrates this described relation based reasoning (cf. Table 2):

\section{Excerpt 2}

$\mathrm{S}_{1}:$ Are the seeds alive?

$\mathrm{S}_{2}:$ No!

$\mathrm{S}_{1}$ : Can seeds breathe?

$\mathrm{S}_{2}$ : Yes! Seeds don't live!

$\mathrm{S}_{1}$ :... in some way they must live... Otherwise - how could they start growing?

$\mathrm{S}_{3}$ : Like the hair...the hair is dead! The nails are dead.

$\mathrm{S}_{1}$ : ... but they live...the answer of the first question is that they live.

$\mathrm{S}_{2}$ : Do they live?

$\mathrm{S}_{3}: \mathrm{No}$ ! 
The students' elaboration showed that it was difficult to understand questions and concepts and they tried to find reasonable answers to these questions and wanted to know more about the processes. They had experiences that they shared with their mates and in these discussions they used logical processes. The comparison that the students made, in this case with the hair, shows development of model based reasoning. In the following excerpt the same students as in excerpt 2 tried to get some help from a teacher, but when they did not they continued as follows:

\section{Excerpt 3}

$\mathrm{S}_{1}$ : ... but we write...

$\mathrm{S}_{2}$ :... what do we call it? ... What shall we write?

$\mathrm{S}_{1}$ : They start to live when they get water

$\mathrm{S}_{3}$ : I will write that it is like the hair!

$\mathrm{S}_{2}$ : But listen to me! They don't live, but they can breathe when you put soil above them.

$\mathrm{S}_{1}$ : Could they really breathe?

$\mathrm{S}_{2}$ : Yes they can breathe ... that's why you should not put too much soil on them...my mother told me that ...

$\mathrm{S}_{3}$ : Did she?

$\mathrm{S}_{2}$ : Yes she did ... because I killed all seeds once.

This discussion shows that they tried to make a model of the living process i.e. model based reasoning.

The written work made the students focus and the group members in all groups mostly wrote the same details in their notebooks. Analyses of students' writings during the plant tasks showed that they used more scientific language when they were describing and explaining in text. They tried to use new scientific words, which were presented to them in the tasks, i.e. they used a logical process and the reasoning was both phenomenon and relation based. Compared to the audio-taped excerpt 1 , there were no noticeable fascination and interest in the written texts, i.e. no excitement and no words like jungle, popcorn and roe. Excerpt 4 is from a fourth grader's written work:

\section{Excerpt 4:}

About garden cress - The germinated seeds are wet and smell more and are paler. The seeds germinate and get stems and roots. The seeds get bigger in the water.

The fourth graders struggled with their writing. The sixth and fifth graders spent less time on each task and could more easily write down their observations and thoughts. However, the content of the written work was almost the same in the fourth to sixth grades, with more scientific words being used than in their discussions.

\section{Almost visible matter - plant cells and stomata}

The next set of tasks was dealing with plant cells and stomata. These tasks confronted the students with new equipment and many new words and concepts. Excerpt 5 shows the fourth graders' difficulties with the task. Using a microscope, answering questions and making observations were difficult because they did not know what they were looking for. A group at the stomata tasks said:

\section{Excerpt 5}

We don't know anything! Only that this is on the backside of a leaf. We were meant to write questions first, but we didn't have any. We hardly knew what this was. (They are telling a teacher this).

When the teacher helped them, they were able to observe and discuss the questions. This happened in all classes, but more frequently in the fourth grade. The fifth and sixth graders were more fascinated when they looked at plant cells and stomata under the microscope, compared to the 
seed and garden cress tasks. The tasks about stomata and cells were important links between the plants and the invisible process of photosynthesis, as shown in Excerpt 6 from some sixth graders' discussions.

$\mathrm{S}_{1}$ : Plants don't need to breathe ...

$\mathrm{S}_{2}$ : They do! ... it is with these (the stomata) that they breathe!

$\mathrm{S}_{3}$ : But I don't believe that they eat air!

$\mathrm{S}_{2}$ : They open up and let the air come in

$\mathrm{S}_{3}$ : No ... where do they have their mouth then?

$\mathrm{S}_{2}$ : They take it with the stomata ... it is things like that they take in ... oxygen and water and such ... through the stomata

$\mathrm{S}_{1}$ : They take in carbon dioxide, oxygen and water. Gases and oxygen! But ... are those things in the air?

$\mathrm{S}_{2}$ : Stomata take in oxygen ... into the stomata ... no!! ... that's wrong! Into the stomata come ... $\mathrm{S}_{1}$ : Shall you not write from stomata ... comes oxygen!!

In Excerpt 6, the students made connections with new words and concepts and they tried to explain parts of photosynthesis when they were looking at stomata. The task made them ask questions despite having not seen stomata before and having problems understanding if the gases mentioned in the task were air or something else. They argued a lot and the discussion was intense, but in the end they made a decision that plants need carbon dioxide and let oxygen out. This reasoning had both logical and cognitive strategies since the students connected new scientific words to their new and old knowledge.

The written questions that followed each task challenged students' knowledge and made them discuss new concepts and words. These questions were important stimuli, together with the tasks, since they made them discuss biological processes e.g. germination. Again the scientific words, like cell and stomata, were more frequently used in their writing, compared to the audio-taped discussion. The students were not familiar with the words, but they did try to use them in the right context in formal writing and thereby used logical moves. Excerpt 7 shows a sixth grade students' written work, after observing chloroplasts in the plant cell. In his reasoning he uses a scientific blood cell model to describe the movement:

\section{Excerpt 7}

About plant cells - There are small plates put together to a big leaf and on the edges; there are thorns/jags and you see small transparent dots moving like blood cells on a highway back and forward...

\section{Invisible matter - water and carbon dioxide}

During the tasks with carbon dioxide and water, three weeks after studying plants, seeds, germs, stomata and cells, the students used the scientific words/concepts that they had encountered in the first week, during the explanations of new scientific phenomena. In the fourth week model based reasoning occurred in all three classes. Students' discussions became more relation based in the fourth week since the students used their new or updated knowledge from the first three weeks. The following quotation comes from a student who had put her hand in a transparent bag and made a comparison with the plants' stomata that she had come across three weeks earlier: There must be stomata in my skin that let water out. This 10-year-old girl was really astonished at the reaction of her hand in a transparent bag. She applied her knowledge from the first week, together with her observations and made a model for her explanation for the water coming out of her skin. The reasoning connected new experiences with scientific processes and all three analysing categories were used. The next explanation, of the state of water aggregation from an 11-year-old boy, was another example:

Water is invisible in the air but becomes visible in the plastic bag. 
The invisible matter confused many students and they struggled with the scientific words/concepts when they did not use the same words in everyday language. The tasks in the fourth week involved water and gases, like carbon dioxide and the students' reasoning showed how confusing the scientific language and everyday language can be for both teacher and students. Even the everyday words were not the same in different contexts. For the students 'mist' could be oxygen, carbon dioxide, water, steam, or air. In fact, none of the suggestions were totally incorrect since air contains all these compounds and water in a gas phase that the students breathed out. When they tried to use the word/concept 'water' in its right context, they did not realise that mist, steam, fog, sweat, warm exhaled air etc. are all words for water in a gas phase, and their discussion confused them.

\section{The interviews}

The interviews confirmed that the students had found the plant project interesting and their reasoning showed how they had developed understanding for photosynthesis. In one of the individual interviews, six months later, a student reasoned like this $(\mathrm{I}=$ interviewer and $\mathrm{S}=$ student $)$ :

\section{Excerpt 8}

I: Why does the plant need carbon dioxide?

S: To live!

I: But what happens with it?

S: I think it grows... it uses it for something and then it changes into oxygen and then it breathes this out and we ... it could be that the leaves grow ... it could be soil ... it could be buds ... maybe new buds...

I: Have you heard about carbohydrates?

S: Yes, that's on the packets ... corn flakes e.g. ... I don't know what it is really ... maybe something that builds up the plant ... it could be energy??

The student made connections with carbon dioxide, living and growing, oxygen, carbon hydrates to build up plants and energy. The reasoning was phenomenon, relation and model based when different explanations were used but all the pieces could not be put together. The language was not scientifically correct but in all the interviews and in Excerpt 8 and 9 the students tried to explain and elaborate on the difficult scientific processes. The interviews also showed their difficulty in understanding what happens to carbon dioxide in the leaf. Carbohydrates are invisible and a word/ concept that is used in many different contexts and another student said:

\section{Excerpt 9}

I: These stomata ... why are there such at the leaves?

S: They take in water? No! Oxygen!

I: Does it take in oxygen? The plant?

S: No, it takes in carbon dioxide...

I: Yes, why?

S: Because it's something in the carbon dioxide ...

I: Yes, and what happens with it?

S: Yes ... then they take it and the thing they don't need they convert into oxygen and they let the oxygen out again ...

I: Exactly! You said that in a very good way. They let oxygen out, but what do they make with the carbon dioxide?

$\mathrm{S}: \ldots$ the carbon dioxide $\ldots$ hmm ... they... they need it to grow I think!

In the interviews all students reasoned with themselves and got support from the interviewer. The interviewer both helped and hindered the students' reasoning. The plant material, pine tree branches, potatoes, carrots and two pot plants, brought to the interviews helped both students and the interviewer. 


\section{Summary}

The plant tasks encouraged the students' scientific reasoning since their questions and explanations about physiology and functions showed both their knowledge and interest to learn more about photosynthesis.

The fourth graders spontaneous and longer discussions made their reasoning more phenomena based and all the students' discussions showed interest to know more about plants. The written work showed more logical processes than their oral work, but in both, when the students tried to explain, make models, and make connections with the new words/concepts or scientific processes, e.g., germination and photosynthesis, they showed an ongoing process of understanding.

The visualized stomata helped students to put into words the transport of gases and the plant cell linked the invisible gases to visible matter in the plant. The individual interviews confirmed that the students had learned about photosynthesis since the students, six months later, showed all of the multiple reasoning perspectives, indicating that understanding existed.

\section{Discussion}

Over a six-week period, we met 68 students (10-12 years old) in their classrooms, working with plant material and tasks connected to plants (Table 1). During that period we studied how students developed their understanding of plant anatomy, photosynthesis and plant life cycles. The students reasoned in small groups, they wrote down their questions and thoughts, and they talked to each other and their teachers. During their work the students studied plants, 'almost visible cells', and invisible gases to make photosynthesis less abstract. The purpose was to let the students observe (see, feel, and taste) with all their senses and to present them to small investigations where the questions confronted them with new words and concepts.

The students showed true enthusiasm during these tasks. They smelled, looked and used their senses and they wanted to share their experiences with their school friends. They were fascinated by e.g. the seeds germination process and a lot of questions arose: What is germination? Do seeds live? When do they start to germinate? Do they need light to germinate? By these questions the students revealed that this area was new to them, and they did not directly focus on photosynthesis, but their questions showed an interest in knowing and understanding more about plants and photosynthesis.

Since our focus was students reasoning there was much data to listen to and analyse. There are many things that happen in the classroom context and the students' reasoning did not only include their discussions. Lemke (1990) called it doing science through the medium of language and he claimed that:

Talking science means observing, describing, comparing, classifying, analysing, discussing, hypothesizing, theorizing, questioning, challenging, arguing, designing experiments, following procedures, judging, evaluating, deciding, concluding, generalizing, reporting, writing, lecturing, and teaching in and through the language of science (Lemke, $1990 \mathrm{p}$. ix).

In our classrooms they observed, described, compared, discussed, questioned, argued, and followed procedures etc. Hence, Lemke's list above depicts the classroom situation.

According to Tomkins and Dale Tunnicliffe's (2001), diary-writing, home tasks and investigations with everyday experiences stimulated the students to spontaneously raise questions and answer them from their own subsequent observations. Our data showed that plant tasks did make photosynthesis interesting and understandable in a classroom context. It also showed the possibility to use more discussions, investigations and laboratory work in science education, which the Swedish 
government has called for (The Swedish National Agency for School Improvement, 2005). The plant tasks also gave the primary school students the empirical references to plants structures and functional processes, which Canal (1999) suggested as a possibility to learn photosynthesis in a useful way. These plant tasks were easy to prepare and work with in an ordinary classroom. Living plant material is important to obtain an ecological understanding (Helldén, 1992; Vikström, 2005). The questions that followed each task guided students' reasoning to new thinking and, like other studies have shown, the primary school students were capable of developing understanding of difficult processes in science (Abd-El-Khalik et al., 2004; Gallas, 1995; Nilsson, 2005; Tytler \& Peterson, 2003; Vikström, 2005).

This study showed that plant tasks can develop understanding for photosynthesis. The 10-12 year old students' discussions during and after the tasks showed all of the multiple reasoning perspectives, indicating that understanding existed (Table 2). Almost all students in this study took part in the discussions. We will argue that when students have the opportunity to discuss they can develop understanding. Other studies, which show that students do not understand the ecological importance of plants and photosynthesis (Andersson, 2000; Bornäs \& Djurvall, 1993; Canal, 1999; Carlsson, 1999; 2002; 2003; Ekborg, 2003; Harlen, 2001; Marmaroti \& Galanopoulou, 2006; Smith \& Anderson, 1984; Wood-Robinson, 1991; Özay, 2003) are often based on questionnaires which ask the questions out of context and do not give the students the opportunity to discuss the questions and their answers. Our study of the discussions shows that the students' scientific language was not correct but, like Rundgren (2006), we mean that students can express a scientific understanding by using non-scientific language.

The students' discussions gave them the opportunity to learn, develop understanding, and to argue about scientific words and concepts. For example, the different words for 'water' distracted them and made 'water' a troublesome concept. They had plenty of ideas from contexts other than school (education), and this knowledge they willingly shared with other students. During our tasks, the students needed help, but their discussions without an interacting teacher made them realize that they needed the teacher's help. It is important that the teacher encourages these discussions in order to raise their students' level of interest and knowledge. With a teachers' help, students' discussions more easily lead to understanding (Andersson, Bach, Hagman et al., 2005; Helldén, 2002; 2005; Lidar et al., 2006; Sjøberg, 2000; Vikström, 2005; Zetterqvist, 2003).

It was obvious that the students used more scientific language when they wrote than when they talked. The writing made them focus on their task and forced them to use the new words and concepts they came across. Many students complained when they had to write and the fourth graders required more time to write than the fifth and sixth graders. If we had only analysed the students' written work our picture of their work with the plants would have looked quite different from an interest and fascination point of view. According to Rivard and Straw (2000), writing together with group discussion is successful when you want to enhance retention of science learning over time and it is possible that one of the reasons that our students remembered so much six months later, could be due to this teaching design.

The process of learning and understanding connected to the plant tasks was, as expected, more phenomenon and relation based than concept/model based. Other investigations (Driver et al., 1996; Tytler \& Peterson, 2003) have shown almost no concept/model based reasoning but that was not the case in this study. The students used all reasoning perspectives in the first and the fourth week and in the interviews six months later. These students knew a lot about plants before they encountered the tasks and the tasks made them ask new questions. Good teacher qualifications in biology are needed, also in the early school years (Harlen, 2001; Vikström, 2005) otherwise the students will not be able to find or get any relevant answers to their serious questions nor opportunities to accomplish investigations where they can find the answers by themselves. We think the teacher's role should be more supportive and confirming than explaining, since the 
students' own thoughts, questions, and knowledge need to be heard. Being careful with new scientific words and concepts is important since these words could have quite different and various meanings in students' everyday language e.g. carbohydrates. Barnes and Todd (1978) concluded that students learn more when they are asked to use their own words to explain their thoughts, especially without teacher influence. Their students showed more knowledge than their teachers expected when they had the opportunity to discuss different tasks. We confirm that this also happened in this study and that both teachers and the interviewer sometimes hindered the students' reasoning, although, the other way around, when the students needed the teachers' help, was a much more common situation.

Carlsson $(1999 ; 2002 ; 2003)$ described how the concepts of particle theory, changes of phase and transformation were difficult to grasp for the students. To see and understand stomata's function and importance was a vital point in this teaching sequence. The students accepted that gas transport in and out of the plants occurred since they had seen stomata and knew where the gases could get in and out. Stomata then became an important link between the visible plant and the invisible gases. In the interviews six months after the project had finished all students interviewed remembered the stomata's function and position. They held the pine tree branch in their hand, explained and pointed out where the tree got its carbon dioxide and that this gas made the tree grow. The interviewed students had a lot of knowledge and probably a pretty good picture of what happens in photosynthesis. The growth connection to carbohydrates was harder to explain and this project and the tasks given did not address this part of photosynthesis in an adequate way.

It was not easy to find suitable places for the equipment, such as microscopes and magnifiers, in an ordinary classroom and there were some problems audio-taping the discussions. However, the possibility to accomplish these teaching sessions in a classroom context far surpasses the problems. A well-functioning microscope in every classroom would be one step closer to a better understanding of photosynthesis and thereby a better ecological understanding.

\section{REFERENCES}

Abd-El-Khalik, F., Boujaoude, S., Duschl, R., Lederman, G.N, Mamlok-Naaman, R. \& Hofstein, A., Niaz, M. et al., (2004). Inquiry in Science Education: International Perspectives. In E. Krugly-Smolska \& P.C. Taylor (Eds.), Culture and Comparative Studies. Wiley Periodicals, Inc.

Andersson, B. (2000). Elevers tänkande och skolans naturvetenskap. Forskningsresultat som ger nya idéer. Göteborgs Universitet, institutionen för pedagogik och didaktik.

Andersson, B., Bach, F., Frändberg, B., Jansson, I., Kärrqvist, C., Nyberg, E. et al., (2005). Formativ utvärdering med fotosyntes som exempel. http://na-serv.did.gu.se/nordlab/se/trialse/pdf/bi3. pdf (2005-05-11).

Andersson, B., Bach, F., Hagman, M., Svensson, M., Vedin, L-G., West, E. et al., (2005). Notlyftet. Kunskapsbygge för bättre undervisning $i$ naturvetenskap och teknik. Göteborgs Universitet, Inst för pedagogik och didaktik. Enheten för ämnesdidaktik.

Barak, J. (1999). As 'process' as it can get: students' understanding of biological

processes. International Journal of Science Education, 21, 1281-1292.

Barnes, D. \& Todd, F. (1978). Communication and learning in small groups. School of Education, University of Leeds and Department of Contemporary Studies, Leeds Polytechnic.

Barnes, D. \& Todd, F. (1995). Communication and learning revisited. Making meaning through talk. Boynton/Cook Publishers, Inc. A subsidiary of Reed Elsevier Inc. Portsmouth.

Bornäs, S.\& Djurvall,B. (1993). Energi och liv. Ett nytt sätt att undervisa om fotosyntesen. In B. Andersson (Ed.) Na-spektrum Studier av naturvetenskapen i skolan Nr 1. Göteborgs universitet. Institutionen för ämnesdidaktik avd för naturvetenskap, Mölndal.

Canal, P. (1999). Photosynthesis and 'inverse respiration' in plants: an inevitable misconception? International Journal of Science education, 21, 363-371. 
Carlsson B. (1999). Ecological understanding - A Space of Variation. Luleå University of Technology

Carlsson B. (2002). Variation och naturvetenskapligt lärande. Forskningsrapport 2002:2 Teachers education Luleå University of technology

Carlsson, B. (2003). Dramatic Photosynthesis. Australian Science Teachers Journal, 49, 26-35.

Driver, R., Leach, J., Millar, R., \& Scott, P. (1996). Young People's Images of Science. Open University Press. Buckingham, Philadelphia.

Dysthe, O. (2003). Sociokulturella teoriperspektiv på kunskap och lärande. In O. Dysthe (Ed). Dialog, samspel och lärande. Studentlitteratur.

Ekborg, M. (2003). How student teachers use scientific conceptions to discuss a complex

environmental issue. Journal of Biological Education , 37(3), 126-132.

Gallas, K. (1995). Talking their Way into Science. Hearing Children's Questions and Theories, Responding with Curricula. Teachers College, Columbia University New York and London.

Harlen, W. (2001). Research in primary science education. Review. Journal of Biological Education, 35, 61-65.

Helldén, G. (1992). Grundskoleelevers förståelse av ekologiska processer. Studia Psykologica et Pedagogica. Series Altera C. Stockholm.

Helldén, G. (2002). En longitudinell studie av lärande om ekologiska processer. In H. Strömdahl (Ed.). Kommunicera naturvetenskap i skolan - några forskningsresultat. Studentlitteratur.

Helldén, G. (2005). Exploring Understandings and Responses to Science: A Program of longitudinal Studies. Research in science education, 35,: 99-122. Kristianstad University.

Leach, J. \& Scott, P. (2003). Individual and Sociocultural Views of Learning in Science Education. Science \& Education, 12(1), 91-113.

Lemke, J. L. (1990). Talking Science. Language, Learning and Values. City University of New York. Brooklyn College School of Education.

Lidar, M., Lundqvist, E., \& Östman, L (2006). Teaching and Learning in the Science Classroom. The Interplay Between Teachers' Epistemological Moves and Students' Practical Epistemology. Science Education, 90, 148-163.

Marmaroti, P., \& Galanopoulou, D. (2006). Pupils' Understanding of Photosynthesis: A questionnaire for the simultaneous assessment of all aspects. International Journal of Science education, 28, 383-403.

Nilsson, P. (2005). Barns kommunikation och lärande i fysik genom praktiska task. NorDina Nordic Studies in Science Education, 1, 58-69.

Rivard, L. P., \& Straw, S. B. (2000). The Effect of Talk and Writing on Learning Science: An exploratory Study. Science Education, 84, 566-593.

Rundgren, C-J. (2006). Att börja tala 'biokemiska' - Betydelsen av metaforer och hjälpord för meningsskapande kring proteiner. NorDina - Nordic Studies in Science Education, 5, 3042.

Sjöberg, S. (2000). Naturvetenskap som allmänbildning - en kritisk ämnesdidaktik. Printed in Sweden, Studentlitteratur, Lund.

Smith E. L., \& Anderson C. W. (1984). Plants as Producers: A Case Study of Elementary Science Teaching. Journal of Research in Science Teaching, 21, 685-698.

Swedish National Agency for School Improvement (2005). Handlingsplan för arbetet med naturvetenskap och teknik. Slutrapport 2005-07-01. Dnr 2005:122.

Tomkins, S. P., \& Tunnicliffe, S. D. (2001). Looking for ideas: observation, interpretation and hypothesis-making by 12-year-old pupils undertaking science investigations. International Journal of Science Education, 23, 791-813.

Tytler R., \& Peterson S. (2003). Tracing Young Children's Scientific Reasoning. Research in Science Education, 33, 433-465.

Vetenskapsrådet [ The Swedish Research Council ] (2002). Forskningsetiska principer inom humanistisk-samhällsvetenskaplig forskning [ Ethical Guidelines for Research ]. (Vällingby: Elanders Gotab). ISBN: 91-7307-008-4 
Vikström, A. (2005). A seed for learning. A variation theory study of teaching and learning in biology. Doctoral thesis no: 2005:14. Department of Educational Sciences. Luleå University of technology.

Wood-Robinson (1991). Young People's Ideas About Plants. Studies in Science Education, 19, 119-135.

Zetterqvist, A. (2003). Ämnesdidaktisk kompetens $i$ evolutionsbiologi. En intervjuundersökning med no/biologilärare. Göteborg studies in educational sciences, 197. Göteborg: Acta Universitatis Gothoburgensis.

Özay, E. (2003). Secondary Student's Interpretation of Photosynthesis and Plant Nutrition. Journal of Biological Education, 37, 68-70. 